gations will no doubt be made of these shocks. A descriptive catalogue of earthquakes of the Pacific coast of the United States from 1769 to 1928 was published in January 1939 by the Seismological Society of America. The recorded shocks for Cali. fornia occupy 231 pages whilst those for the remainder of the coast occupy 44 pages.

\section{Soviet Census}

More complete figures relating to the census of the Soviet population taken on January 17, 1939, have been issued by the State Planning Commission of the U.S.S.R. The figures cover the entire population of the Union with the exception of the far north, where the census will be taken in the latter half of this year. The figures issued reveal that on January 17 last, the population of the Soviet Union numbered 170,467,186, including 81,661,981 males and 88,802,205 females. As compared with the census of 1926, the Soviet population has increased by $23,439,271$ or by $15 \cdot 9$ per cent, the urban population being $55,909,908$ or 32.8 per cent of the total, as against $26,314,114$ in 1926 , or $17 \cdot 9$ per cent of the total. Owing to a typographical error in the note which appeared in NATURE of June 3 (p. 936), relating to preliminary figures of tho Soviet census, it was stated that the entire population had more than doubled. This should have read "the urban population has more than doubled". The average annual increase of population in the U.S.S.R. during the period 1926-39 was $1 \cdot 23$ per cent. The increase in the birth-rate is illustrated by figures relating to some of the big towns of the Union. In 1938 the average number of births per thousand of population in Moscow was 28.5 , Leningrad 27.4 , Kiev 27.4, Kharkov 27.7, Baku 33.9. There are 174 towns in the U.S.S.R. with populations of more than 50,$000 ; 82$ have populations of more than 100,000 and eleven have populations of more than half a million. The population of Moscow has increased from $2,029,425$ in 1926 to $4,137,018$ in 1939 , or by 103.9 per cent, and that of Leningrad from $1,690,065$ in 1926 to $3,191,304$ in 1939 , or by 88.8 per cent. Four towns are included in the 1939 census which did not figure on the geographical maps in 1926, namely, Karaganda which now has a population of 165,937 , Magnitogorsk with a population of 145,870 , Stalinogorsk with a population of 76,207 , and Komsomolsk-on-Amur with a population of 70,746 . During tho period 1926-39, 1,536 new urban centres, 213 of which have been constituted as towns, have sprung up on the territory of the Soviet Union.

\section{Pulkovo Observatory}

THe chief observatory in the U.S.S.R., situated at Pulkovo, a fow miles outside Leningrad, celebrates the hundredth anniversary of its foundation this year. To-day a number of buildings devoted to astronomy and related sciences surround the original central edifice, with its circular hall through the middle of which runs the Pulkovo meridian. This hall is now used as the observatory's museum, and it contains some extremely interesting exhibits, including a working model of the solar system, made by an unknown craftsman 150 years ago. Not only do the earth and planets revolve around the sun in this model, but also tho glass shade which covers it is utilized for representation of the stars and constellations. The library, situated in a gallery around the main dome, contains some very valuable unique works, including Kepler manuscripts. The Pulkovo Fundamental Catalogues of Stars are widely known for the accuracy of the observations entered in them. Needless to say, the observatory is also rich in astronomical photographs and similar research materials. At the time of its foundation the refractor installed in the observatory, one with a lens of fifteen inches diameter, was the largest in the world. It was added to in 1885 by tho installation of another refractor with a thirty-inch lens.

\section{Positive Eugenic Policy}

IN his Galton Lecture, Dr. C. G. Darwin discussed a positive eugenic policy (Eugenical News, 31, No. 1). He pointed out that a eugenic policy could only exist under conditions of civilization. In centuries up to the nineteenth, populations were stationary or increased but slowly. Then wages began to rise or the price of wheat went down, and with it the mortality rates in infancy and adulthood. It was no longer essential to have a certain level of intelligenco in order to stay alive. Natural selection ceases to operate in civilization, and the things on which surpluses shall be spent are determined by advertisements. The relativo absence of natural selection inevitably leads to degeneration unless eugenic selection can take its place. As regards negative eugenics, the propagation of mental weakness is much more serious than the transmission of a bodily weakness with a high intellect. As regards positive eugenics, we need not wait for full knowledge of the human genetic constitution, to construct human beings as an engineer constructs a bridge. Quite enough is already known with reasonable probability for immediate eugenic action. Bohr's principle of complementarity, implying a mutual effect of subject and object, comes in here. The need is urgent for a simple national eugenic policy which will induce the better endowed to have larger families, and history will not spare us if we do not set to work at once to carry it out.

\section{Forestry at Oxford}

A stature amending the regulations for the School of Forestry at Oxford has recently been approved and comes immediately into force. Hitherto the normal avenue to the final examination has been a special preliminary examination of a comparatively simple nature that could be taken by the student, if he wished, before he came into residence. Now the prior qualifications required of candidates for the final examination are so much higher that the School becomes, in part at least, a post-graduate one. Candidates are now required to have obtained honours in the new Science Moderations examination or in some final school or to be graduates of another 
university and they must have passed approved examinations in botany, geology, physics and chemistry if these have not been taken in the degree courses. The reason for this change, and the concurrent change in the curriculum of the School, is found in the requirements of the forest services and the development of forestry in the Empire. It has been decided also that after August of this year the Imperial Forestry Institute, established in 1924 and controlled by a director other than the professor of forestry since 1936 , is to be joined to the professor's department as a self-contained unit under the immediate charge of the professor. Between 1920 and 1938, 324 men have been trained in the School of Forestry, 258 of whom have passed into the various forest services. During the fifteen years of the independent existence of the Institute, there have been 350 students in attendance.

\section{International Bibliography of Agricultural Economics}

Tue International Institute of Agriculture at Rome has just issued the first number of a new quarterly publication-the International Bibliography of Agricultural Economics-compiled under tho technical direction of the librarian, Dr. S. von Frauendorfer. The neod for a bibliography of this nature was realized in 1932 , and since 1933 twolvo publications on these lines have appeared in the journal Berichte über Landwirtschaft (Parey, Berlin). The thirteenth issue, giving tho literature up to June I, 1938, will bo found in tho Berichte as usual, but subsequent publications are given in the new volume. The International Bibliography of Agricultural Economics covers the economic and social aspects of agriculture, such as agricultural economics, agricultural policy, settlement, credit, co-operation, insurance, marketing, prices, statistics, farm organization and management, valuation, labour, accounting, rural sociology, agricultural history and geography, legislation and education and all other agricultural problems, in so far as they aro considered from the economic and social point of view. Only publications of purely technical character are excluded. Titles of all publications, whether books, bulletins, pamphlets or articles in periodicals, are indicated, including all bibliographical details required for proper identification. All langunges receive equal treatment, and titles in the less linown languages are provided with a translation. The bibliography, which is the only one covering systematically the world literature on agricultural economics, is carefully classified by subjects. An author index will be supplied at the end of each volume. The annual subscription, postage included, is $6 s$. $6 d$.

\section{Seale-Hayne Agricultural College}

TuE criticism is frequently made that the investigations of colleges and research institutes are not reported to the farmer in a form that can be easily understood. To meet this need, and at the same time to make the work of the College more widely known, Seale-Hayne Agricultural College, Nexton Abbot, Devon, is issuing an annual in which it is hoped to deal with a wide variety of subjects in a manner likely to prove of real value to the practical man. The first number has just been published. It contains articles on the chemical composition of broccoli, potato eelworm, varieties of winter oat, and on the animal husbandry side, efficiency factors in the production of bacon pigs, milk production costs and the building up of a tuberculosis-free dairy herd. A list of investiga. tions in progress at the College and of pamphlets already published is appended. Though of particular value to farmers and growers in the south-west of England, the volume will no doubt bo also of interest to agriculturists in other districts.

\section{The John Innes Horticultural Institution}

Tin John Innes Horticultural Institution is unique in Great Britain in combining research in genetics, cytology and biochemistry with pomology and horticulture. The twenty-ninth annual report contains the results of the investigations during the year 1937-38. Two interesting discoveries in cytology were that the chiasmata in the megasporocytes were less randomly distributed than in the microsporocytes of Lilium testacum and that the centromere could divide sometimes transversely as well as longitudinally. The genetical analysis of Tropaeolum, Streptocarpus, Verbena, Zea, Lotus and Primula sinensis is pro. ceeding. There are two linkage groups of most of the identified colour genes in Streptocarpus; both groups oxhibit tight linkage between the genes. 16 genes of Verbena may bo assorted into five linkage groups. The investigation of Rubus species has shown that different varieties, usually polyploid, may be (1) sexual, (2) apomictic, or (3) partly sexual and partly apomictic in reproduction. Even the apomictic varieties can segregate, thus indicating that the first division of meiosis occurs in these forms. The Bio. chemistry Department has been investigating several interesting now plant pigments such as dunnione in Streptocarpus Dunnii and anthocyanins from ferns and unusual sap-soluble substances in Celosia. The training of gardeners and the investigation of suitable soil composts again met with success and good uso was made of the provision of research facilities for visitors.

\section{Bibliography of Seismology}

WE have recently received vol. 12, No. 19 (July, August and September 1938) of the Bibliography of Seismology, published by the Dominion Observatory at Ottaws. This time 117 works are listed and there aro twenty-six collaborators representing 12 countries. It contoins references among many notable works to Dr. C. Davison's "Studies on the Periodicity of Earthquakes" and works by Gutenberg and Richter, Lynch, and Bullen all bearing on the problem of the earth's central core. Particularly interesting is the notice of the article on Frank Lloyd Wright from Readers Digest, directing attention to the importance of the design of buildings in earthquake-troubled countries. Wright designed tho Imperial Hotel in Tokyo to withstand earthquake shocks, and it has done so. 